\title{
DASAR-DASAR POLITIK ISLAM (Upaya Membangun Paradigma Ilmu Politik Islam)
}

\author{
Fauzan Ali Rasyid \\ Dosen Fakultas Syariah dan Hukum \\ Universitas Islam Negeri Sunan Gunung Djati Bandung
}

\begin{abstract}
Abstrak
Tulisan ini akan menjelaskan tentang polemik tentang sistem pemerintahan yang beragam mulai dari masa Rasulullah SAW. yang hingga masa sekarang. dalam konteks siyasah/politik Islam muncul pula tarik-menarik pemikiran konsep kekuasaan yang mengkutubkan antara hak Allah dan Hak manusia. Pemikiran politik Islam yang direduksi dari konsep kesejarahan dan penafsiran terhadap teks-teks wahyu syarat dengan multi tafsir dan perdebatan, sehingga berujung pada tipologi paradigma ilmu politik Islam. Oleh karena itu, tulisan ini secara ringkas akan memaparkan bagaimana dinamika pemikiran tentang politik Islam dalam ranah fiqib al-syasah.
\end{abstract}

\section{Kata Kunci:}

Kekuasaan, Pemerintahan, Politik Islam, Fiqib al-Syasah

\section{A. Pendahuluan}

Eksistensi politik Islam sengat diakui keberadaannya baik oleh para ilmuwan politik maupun para praktisi politik. Pengakuan tersebut dilihat dari dua sisi yakni dari sisi doktrinal dan dari sisi historial. Kedua sisi tersebut menunjukkan tak terbantahkannya keberadaan perkembangan politik Islam. Akan tetapi seiring dengan perkembangan ilmu pengetahuan, politik Islam tersebut dituntut untuk diintitusikan dalam kerangka keilmuan, sehingga keberadaannya bukan hanya merupakan rangkaian sejarah tetapi berupa teoriteori politik yang dapat dikembangkan didunia perguruan tinggi. Sebab kalau politik Islam tidak dibangun struktur keilmuannya mungkin akan dianggap sebagai cerita, sejarah, dongeng atau ulah dari politisi untuk menarik simpatik dengan menonjolkan ikatan- 
ikatan ideologis Islam. Hal tersebut akan memudarkan makna dari politik Islam itu sendiri, sehingga perlu dibangun paradigma ilmu politik Islam. ${ }^{1}$

Pembahasan tentang politik senantiasa berkaitan dengan wilayah-wilayah kekuasaan yang meliputi asal-usul kekuasaan, legitimasi kekuasan, otoritas kekuasaan, fungsi kekuasaan, pengelolaan kekuasaan dan suksesi kekuasaan. ${ }^{2}$ Berdasar itu muncullah berbagai model teori dan pemikiran. Dari berbagai model dan pemikiran substansial yang sering diperdebatkan adalah konsep kedaulatan yang menjadi sumber legitimasi dari kekuasaan. Pemikir tradisional senantiasa beranggapan bahwa kekuasan adalah hal yang abstrak yang terlegitimasi dari cahaya nurbuat. Kelompok pemikir rasional/modern senantiasa beranggapan bahwa kekuasaan adalah hal yang konkrit yang bersumber dari legitimasi rakyat sehingga muncul slogan suara rakyat suara Tuhan. ${ }^{3}$

Berkaitan dengan hal tersebut dalam konteks siyasah/politik Islam muncul pula tarik-menarik pemikiran konsep kekuasaan yang mengkutubkan antara hak Allah dan Hak manusia. Terminologi itu muncul sebagai aplikasi dari model teologi yang dianut oleh berbagai pemikir Islam yang melahirkan pemikiran politik Islam. Dalam konteks itu akan di kupas secara singkat dimana sebenarnya esensi dari konsep kedaulatan politik dalam Islam yang memadukan antara hak Allah dan hak hamba. Dalam uraian di bawah ini akan mengupas hakekat kekuasan adalah milik Allah, isyarah nash dan pemikiran politik muslim tentang negara, hakekat kekuasaan Allah, dan faktorfaktor ikhtilafiyah.

\section{B. Hakekat Kekuasaan adalah Milik Allah SWT}

Perspektif etimologi eksistensi Allah dalam al-Qur'an, ada yang

1 Lihat Mohammed Arkoun, Nalar Islami dan Nalar Modern: Berbagai Tantangan dan Jalan Baru, (Jakarta: INIS, 1994) terutama pada pembahasan "Demi Islamologi Terapan” hlm. 113-125

2 Lihat Robert E. Goodin dan Hans-Dieter Klingemann, A New Handbook of Political Scinece, (New York: Oxford University Press, 1996) terutama pada bab I hlm 3-97 dan John Dunn dalam David Held, Political Theory Today, (Cambridge: Polity Press, 1995) hlm. 23-47

3 Lihat Miriam Budiardjo, Aneka Pemikiran Tentang Kekuasaan dan Wibawa (Jakarta: Sinar Harapan, 1991), hlm 9-29 
menggunakan kata Allah ada pula yang menggunakan Rabb. Al-Illah, yang berartri " $A l-M a$ 'bud" Yakni Tuhan tempat menyembah. Maka jelas Al-Ma'bud berarti yang memiliki 'ibadah. Adapun $A r-R a b b^{5}$ artinya Sang Penguasa. Kadang Ar-Rabb berarti Pemilik dan Yang Dipertuan, seperti dalam kalimat : Rabb al-Maal (pemilik harta), dan Rabb al-Daar (tuan tanah, tuan kerajaan). Maka segala tindakan yang dilakukan seseorang harus sesuai dengan instruksi Rabb.

Di dalam al-Qur'an, berkali-kali Allah menjelaskan, bahwa Ia adalah Pencipta alam Semesta; Tuhan segala yang ada dan Penguasa Mutlak, sedangkan semua manusia adalah hamba-Nya. Manusia sebagai makhluk sama dalam pandangan Allah. Semua makhluk yang hidup dalam kerajaan atau Negara Allah harus patuh dan tunduk kepada segala perintah dan peraturan-peraturan-Nya. ${ }^{6}$

Berdasarkan penegasan al-Qur'an tersebut, maka Negara adalah kepunyaan Allah, demikian pula kedaulatan Negara adalah milik Allah sendiri. ${ }^{7}$ Sedangkan untuk mengurus negara (kerajaan) Allah di atas bumi ini, maka Allah memberi mandat kepada manusia yang disebut dengan khalifah. ${ }^{8}$ Dalam memerintah seorang khalifah diberikan rambu-rambu bahwa kekhalifahan adalah sebagai ujian dan percobaan, dengan suatu peringatan bahwa Allah di samping sangat Pengampun juga cepat memberi hukuman kepada orang yang bersalah.' Adapun tugas utama dari manusia yang telah diangkat menjadi "Kalifah" Allah di atas bumi mewujudkan kemakmuran di muka bumi. ${ }^{10}$

Setelah ada penegasan yang demikian, maka Allah menandaskan dengan lebih gamblang lagi, bahwa Allah selalu dapat mencabut mandat yang telah diberikan kepada sesuatu "umat" atau kepada seseorang "pribadi", apabila umat atau pribadi tersebut nyata telah menyeleweng dari jalan Allah, dan kemudian mandat "Khali-

${ }^{4}$ Al-Ghazali, Nasehat al-Mulk, Dra al-Fikr, t.t, 107

5 Ibid

${ }^{6}$ Lihat Syaikh Muhammad Husain Fadlullah, Islam \& Logika Kekuatan, (Bandung: Mizan, 1995)

7 Lihat Q.57:5, 57:6, 67:1, 42:49

8 Lihat Q.2:30

9 Lihat Q.6: 165

${ }^{10}$ Lihat Q.11:61 
fah" itu diserahkan kepada umat atau pribadi yang lain. ${ }^{11}$

Pemberian kuasa (mandat) dapat diklasifikasikan kepada dua kategori yaitu ada yang bersifat umum dan ada pula yang bersifat khusus. Yang bersifat umum, yaitu kepada manusia diberikan mandat untuk memakmurkan bumi dalam arti seluas-luasnya dan sebagai orang yang pertama diberi kuasa secara umum itu, yaitu Nabi Adam. ${ }^{12}$ Sedangkan yang bersifat khusus, yaitu pemberian kuasa dalam bidang hukum. Dalam bidang hukum terbagi kepada dua macam yaitu, mandat yang diberikan kepada negara. Dan mandat yang diberikan kepada pribadi ${ }^{13}$.

Pemberian kuasa dalam bidang hukum ini, baik kepada negara atau pun kepada pribadi, adalah suatu karunia dari Allah kepada manusia setelah mereka diberi kuasa secara umum. ${ }^{14}$ Sedangkan Pemberian kuasa (mandat) kepada negara, berarti: Pembebasan dan pemberian hak kepada umat untuk memerintah diri sendiri dengan mendirikan negara untuk melindungi segala kepentingan rakyat dan meningkatkan derajat bangsa. Perluasan kekuasaaan negara atas keseluruhannya.

Pemberian kuasa (mandat) kepada pribadi yaitu menguasakan kepada seseorang untuk menjadi pemimpin negara. orang yang diberi kuasa itu, ada kalanya Allah menamakannnya dengan Khalifah. ${ }^{15}$ Dan kadang-kadang Allah menamakan "mandataris"-Nya itu dengan "Imam"16. Pada waktu yang lain, Allah menamakan "mandataris"Nya itu dengan sebutan "Malik"17 atau "Raja."

Pemberian kuasa (mandat) kepada manusia sebagai Khalifah untuk memakmurkan bumi ini, tidaklah dimaksudkan boleh berbuat sesuka hati tanpa adanya sesuatu ketentuan hukum, akan tetapi tidak akan dibiarkan berbuat sesuka hatinya tanpa adanya pengawasan. Mandat yang diberikan kepada khalifat tersebut dengan ketentuan,

\footnotetext{
${ }^{11}$ Lihat Q.3:26.

${ }^{12}$ Lihat Q.2:30 1984) hlm. 30

13 A. Hasjimy, Di Mana Letaknya Negara Islam, (Surabaya: PT. Bina Ilmu, ${ }^{14}$ Lihat Q.28:5, 32:24 (Q.38:26)

15 Komaruddin Khan, Pemikiran Politik Ibn Taimiyah, hlm. 103 dan lihat

${ }^{16}$ Ibid dan lihat Q.2:124, Q.21: 73

${ }^{17}$ Ibid dan lihat Q.5:20, Q.2:247
} 
tetap beribadat kepada Allah saja, melaksanakan perintah-Nya, menjauhi larangan-Nya. Kalau dengan pemberian mandat itu, kepada manusia telah diberikan beberapa hak, maka dengan itu pula kepada mereka diberikan lebih banyak kewajiban. ${ }^{18}$

\section{Isyarah Nash dan Pemikiran Muslim tentang Keharusan Adanya Negara.}

1. Landasan Syar'i

Al-Qur'an dengan tegas telah menetapkan keharusan adanya "Negara" dan telah menggariskan pula tujuan daripada negara. Hanya negara yang dimaksud tersebut secara tekstual tidak ada yang menunjukkan suatu model atau batasan tentang negara itu sendiri, sehingga melahirkan multitafsir. Apakah negara dengan membatasi wilayah atau kesukuan? Atau negara yang berlandaskan ikatan ideologis (Islam) sebagaimana yang terjadi pada masa imperium? Atau seperti nation state dari pemikiran Barat? Semua itu menjadi dinamika/ikhtilaf dikalangan politisi Islam.

Berkaitan dengan tidak ada tekstualnya model negara, akan tetapi terdapat beberapa isyarah yang menunjukkan tentang kenegaraan itu sendiri dan semua itu dicerminkan oleh beberapa Nabi dan Rasul Allah seperti Nabi Daud as., Nabi Sulaiman as., Nabi Yusuf as., termasuk Nabi Muhammad saw., di mana Allah memerintahkan Rasul-Nya untuk membiasakan dan berlatih diri dalam urusan-urusan kenegaraan, sebagimana halnya perintah yang serupa juga ditujukan kepada segenap kaum muslimin. ${ }^{19}$

Kalau dalam ayat tersebut tertera janji Allah kepada kaum mukmin yang berbakti akan diangkat menjadi pemimpin dunia (khalifah), agamanya (Islam) akan kekal abadi, kehidupan cemas akan diganti dengan kehidupan damai bahagia, ini semua tidak akan dapat berlaku tanpa ada negara dan pemerintahan.

"Dengan karunia Allah engkau (hai Muhammad) bersikap lunak terhadap mereka, dan andaikeata engkau berkepala batu serta berhati batu, pasti mereka akan menjaubi engkau. Berilah mereka maaf dan

\footnotetext{
${ }^{18}$ Lihat Q.22:41

${ }^{19}$ Lihat Q.24: 55
} 
ajaklah mereka bermusyawarah dalam urusan (pemerintahan)",20

"Kami telah menyampaikan kepada engkau (hai Muhammad) Kitab yang mengandung kebenaran, supaya dengan petunjuk. Allah itu engkau cakap memerintah manusia',21

Kalau ayat-ayat yang ditujukan kepada Muhammad SAW tersebut, membawa berita ajakan agar Muhammad SAW membiasakan diri dengan berbagai urusan, peradilan, peperangan, administrasi pemerintahan, musyawarah dan sebagainya, maka semua itu baru dapat dilaksanakan dengan adanya negara dan pemerintahan. Terdapat pula petunjuk Allah yang berkaitan dengan ketentuanketentuan Hukum Pidana seperti qishash bagi orang-orang yang dibunuh, ${ }^{22}$ kewajiban berjihad, ${ }^{23}$ bersifat amanah dan berlaku adil, ${ }^{24}$ taat kepada Allah, Rasul dan Kepala Pemerintahan, ${ }^{25}$ memotong tangan pencuri, ${ }^{26}$ memperlengkapi diri menghadapi musuh, ${ }^{27}$ menunaikan janji dengan pihak lawan. ${ }^{28}$

\section{Landasan Historis}

Perbincangan tentang ketatanegaraan dan pemerintahan dalam konteks Islam perlu merujuk kepada negara yang dibangun oleh Nabi Muhammad Saw. Sebab negara yang dibangun oleh Nabi tersebut diakui oleh para ahli sejarah sebagai model negara paling modern. Negara Nabi yang bernama negara Madinah tersebut memenuhi syarat ketatanegaraan modern sebab negara tersebut mempunyai wilayah kekuasaan, penduduk, pemerintahan dan konstitusi. Yang lebih penting dari itu adalah persyaratan yang terakhir yaitu konstitusi. Konstitusi negara Madinah merupakan dokumen autentik tertulis dari suatu bentuk awal pemerintahan
${ }^{20}$ Lihat Q.3:159
${ }^{21}$ Lihat Q.4:105
${ }^{22}$ Lihat Q.2:178
${ }^{23}$ Lihat Q.2:190
${ }^{24}$ Lihat Q.4:58
25 Lihat Q.4:59
26 Lihat Q.5:38
${ }^{27}$ Lihat Q.8:60
${ }^{28}$ Lihat Q.64:4 
konstitusi di dunia ${ }^{29}$. Dan konstitusi ini telah dideklarasikan, jauh sebelum negara-negara yang sekarang mengklaim dirinya sebagai bangsa modern yang beradab, seperti Amerika Serikat, Inggris dan Perancis.

Akan tetapi, sepeninggal Nabi Muhammad Saw mulai timbul persoalan suksesi pemimpin umat yang kemudian melahirkan lembaga khilafah. Walaupun pada awal pembentukannya mengalami sedikit kemacetan dan kontroversial tentang siapa yang paling berhak di antara para shahabat dan golongan mana yang paling layak menduduki kursi kekhalifahan, namun akhirnya Abu Bakar terpilih sebagai khalifah pertama.

Persoalan yang muncul dikemudian hari ialah masalah fungsi dan peranan khalifah. Apakah khalifah itu berfungsi sebagai pemimpin agama dan keduniaan ataukah salahsatunya saja. Sejarah menunjukan bahwa khalifah berfungsi sebagai kepala dan pemimpin agama dan keduaniaan (negara), terutama pada masa khalifah empat pertama. Pada babakan sejarah tercatat bahwa fungsi khalifah hanya sebagai pemimpin keduniaan atau kepala negara, terutama setelah munculnya konsep sultan di samping al-khilafah.

Para penulis politik Islam seperti al-Mawardi (974-1058) dan Ibn Khaldun (1332-1406) menyatakan bahwa khalifah adalah suksesi kenabian dalam memelihara agama dan mengatur keduniawian. Kedua pakar ini mendefinisikan khilafah secara fungsional. Namun demikian Ibn Khaldun kemudian membedakan antara instusi khilafah dan kerajaan (al-mulk).

Kepemimpinan umat Islam mengalami kemajuan yang luar biasa, terutama pada masa al-khulafa al-Rasyidun, Muawiyah dan berpuncak pada zaman Abasiyah, terutama pada masa Khalifah Harun al-Rasyid dan Khalifah al-Makmun. Keberhasilan dalam kepemimpinannya menjadi rujukan ideal dalam pola kepemimpinan umat. Pada masanya menerapkan perinsip-perinsip hukum Islam dalam ketatatnegaraan dan pemerintahan dengan sungguh-sungguh. Perinsip tersebut antara lain: al-burriyah (kebebasan), al-'adl (keadilan),

${ }^{29}$ Montgomery Watt, Muhammad Prophet and Statesmen, (New York: Oxford University Press, 1991), hlm. 94 dan lihat juga A. Djazuli, Fiqib Siyasah, Implementasi Kemashlahatan Ummat dalam Rambu-rambu Syariah, ( Jakarta Timur: Kencana, 2003) hlm 20-38 
274 | Adliya, Vol. 8 No. 1, Edisi: Januari-Juni 2014

al-musawah (persamaan), al-syu'ra (musayawarah) dan ditambah lagi dengan dua perinsip tambahan yaitu al-mu'aradah (pengawasan) dan al-naqd al-dha'thiy atau mubasabat al-nafs (membuka kelemahan atau kekerangan diri sendiri) ${ }^{30}$

\section{Beberapa Ijtihad Politik Pemikiran Muslim (Timur Tengah)}

Terdapat beberapa pemikir muslim terutama yang berpendapat di Negara-negara Timur Tengah yang merupakan awal berkembangnya Islam. Para pemikir tersebut mengemukakan beberapa pemikiran baik secara filosofis maupun secara praktis tentang perlunya sekaligus model dari sebuah negara Islam, tetapi semua itu berbentuk sebuah penafsiran/interpretasi dari teks al-Qur'an dan pengalaman bernegara. Sehingga berdampak munculnya berbagai macam model dari bentuk negara Islam. ${ }^{31}$

Seperti yang dikemukakan Ibn Khaldun $^{32}$ tentang makna negara dan pemerintahan bahwa adanya masyarakat manusia adalah suatu keharusan. Hal tersebut diistilahkan "watak manusia senantiasa berhaluan maju", yang berarti bahwa adanya masyarakat adalah suatu keharusan dengan istilah disebut "al-Madaniah".

Lebih lanjut Ibn Khaldun mengatakan bahwa Allah SWT., telah menjadikan manusia dengan fitrah yang sempurna, tetapi ia tidak akan mampu hidup dengan sendirinya ia pasti membutuhkan pertolongan orang lain mulai dari mempertahankan hidup untuk mendapatkan makanan maupun untuk membela diri dari serangan yang lain, sehingga dibutuhkan hidup secara sosial.

Kemudian, setelah terbentuk masyarakat manusia dan sempurna kemajuan dunia, maka menjadi keharusan pula adanya seorang pemimpin dalam kalangan mereka untuk menghindari perceksokan, yang ditimbulkan oleh mereka yang suka bermusuhan dan kejam atau melindungi dari permusuhan sesamanya. Pemimpin yang di maksud itu haruslah salah seorang di antara mereka yang berwibawa

30 Munawir Sadzali, Islam dan Tata Negaan, Ajaran, Sejarab dan Pemikiran, (Jakarta: 1995), hlm. 4

${ }^{31}$ Lihat Anthony Black, Pemikiran Politik Islam, Dari Masa Nabi Hingga Masa Kini, (Jakarta: Serambi, 2001)

${ }^{32}$ Ibn Khaldun, Muqaddimah, Dar al-Fikr.., t.t., hlm. 114 
dan berpengaruh, sehingga sanggup mencegah timbulnya permusuhan.

Sayyid Muhammad Rasyid Ridha ${ }^{33}$ menjelaskan bahwa: "Telah sepakat salaf umat dan ahlus sunnah serta golongan-golongan lain, bahwa pengangkatan imam, artinya pemberian mandat kepadanya untuk memerintah umat, hukumnya wajib atas kaum muslimin, tidak saja menurut akal, bahkan juga menurut syar'i."”

Adapun menurut Al-Mawardi, ${ }^{34}$ hukum mendirikan imamah atau memilih kepala negara adalah wajib syar'i, yakni kewajiban berdasarkan syari'ah; bukan kewajiban berdasarkan akal atau wajib 'aqli. Alasan al-Mawardi adalah ijma para sahabat yang berlandaskan pada Al-Quran surat ke-4 ayat 59. Kewajiban tersebut termasuk kategori fardl kifayah, yakni tanggung jawab bersama seluruh umat. Atas dasar pemikiran serupa ini, dalam proses pemilihannya, AlMawardi membagi masyarakat menjadi dua golongan. Pertama $a b l$ Halli wal aqd atau abl ikhtiyar, mereka ini adalah orang-orang yang akan memilih kepala negara yang terdiri dari para ulama dan cendikiawan serta para pemuka masyarakat dari seluruh negeri. Dan hasil pemilihannya dianggap valid karena merupakan hasil persetujuan yang bulat (ijma). Tugas penting lain menurut Al-Mawardi dari golongan ini adalah harus melakukan penelitian atas kandidat kepala negara, untuk mengetahui apakah ia layak menjadi kepala negara. Jika layak maka ia diminta kesediaannya lalu ditetapkan yang kemudian diikuti oleh pembai'atan; kedua, adalah golongan yang memenuhi persyaratan untuk menjadi kepala negara atau abl al-imamah

Yang dimaksud oleh Mawardi ${ }^{35}$ dengan Imam adalah kepala negara, khalifah, raja atau sultan, dan dengan demikian Mawardi memberikan juga baju agama kepada jabatan kepala negara disamping baju politik. Menurutnya, Allah mengangkat untuk umatnya seorang pemimpin sebagai pengganti (khalifah) nabi, untuk mengamankan agama, dengan disertai mandat politik. Dengan demikian seorang imam disatu pihak adalah pemimpin agama dan dilain pihak sebagai pemimpin politik.

\footnotetext{
${ }^{33}$ Rasyid Ridha, Al-Kbilafah, t.t., hlm. 10

${ }^{34}$ Al-Mawardi, Al-Abkam Asy-Syulthaniyah, t.t., hlm. 117

${ }^{35}$ Ibid
} 
Al-Ghazali ${ }^{36}$ adalah pemikir yang mempunyai pandangan politik dan pemikir politik yang memberikan pengertian politik lebih luas dari pada pengertian politik yang berkembang dewasa ini. Menurut al-Gazali politik (siyasah) segala upaya untuk memperbaiki kehidupan mahluk Allah dan menunjukkan kejalan yang benar dan menyelamatkan mereka didunia dan akhirat. nilai politik tertinggi baginya adalah politik para nabi sebab objek mereka meliputi aspek lahir dan batin.

Ketatanegaraan dan pemerintah (khalifah) dalam pandangan Al-Ghazali adalah termasuk ke dalam bidang fiqh, bukan bidang yang diurus oleh kaum teolog (mutakallim) ataupun para filosof. Pendiriannya ini kiranya dijadikan untuk menentang teori-teori politik golongan mutakallim sebelumnya seperti Mu'tazilah, Syi'ah dan para filosof muslim lainnya.

Penempatan khalifah dan permasalahannya didalam bidang fiqh menjadikannya sebagai persoalan hukum yang mana ukuranukuran fiqh menjadi tolok ukur dan alat penilaiannya. Jika demikian, maka masalah khilafah dalam arti pemerintahan dan ketatanegaraan dapat diselesaikan berdasarkan dan sesuai dengan konteks ruang dan waktu dimana kaum muslimin berada. Pola dan tipe serta corak pemerintahan dan ketatanegaraan tidak wajib dan mesti sama bagi seluruh umat Islam.

Al-Ghazali sependapat dengan al-Mawardi mengenai kewajiban mendirikan khilafah. Akan tetapi, ia memperkaya argumennya dengan ijma' al-ummah. Menurutnya, sejak Nabi Muhammad Saw mendirikan khalifat di Madinah hingga masa hidup Al-Ghazali, umat Islam tidak dapat dilepas dari khilafah. Ijma dalam konsep AlGhazali merupakan sesuatu yang "asing” dikalangan ahli-ahli hukum sunni. Ijma yang lazim dijadikan argumen sunni adalah "konsensus seluruh ulama mujtahid dalam suatu periode tertentu tentang masalah-masalah hukum syari'at..."37.

Menurut Al-Ghazali ${ }^{38}$ kekuasaan kepala negara tidak datang dari rakyat seperti pendapat Mawardi, tetapi dari Allah, yang diberikan hanya kepada sejumlah kecil hamba pilihan. Oleh

\footnotetext{
${ }^{36}$ Al-Ghazali, Op.Cit., hlm. 20

${ }^{37}$ Abu Zahrah, Asyizasah asy-Syar'iyah, t.t., hlm. 45

${ }^{38}$ Ibid
} 
karenanya kekuasaan kepala negara adalah muqaddas atau suci. Juga kepala negara sebagai bayangan Allah di bumi, hukumnya wajib bagi rakyat dari tingkat manapun untuk taat mutlak kepadanya, dan melaksanakan semua perintahnya. Dengan kata lain sistem pemerintahan Al-Ghazali dapat dikatan teokrasi. Oleh karena itu Al-Ghazali tidak membicarakan tentang cara atau mekanisme pengangkatan kepala negara karena menurut pemikirannya bahwa kekuasaan kepala negara itu datang dari Tuhan dan bukan dari rakyat, maka dapat pula dimengerti bahwa Al-Ghazali tidak menyinggung soal dapat atau tidaknya seorang kepala negara digeser dari singgasananya.

Sedangkan menurut Al-Maududi ${ }^{39}$ Terdapat tiga dasar keyakinan atau anggapan yang melandasi pemikiran Maududi tentang kenegaraan menurut Islam. Pertama, Islam adalah suatu agama yang paripurna, lengkap dengan petunjuk untuk mengatur semua segi kehidupan manusia. Kedua, Kekuasaan tertinggi yang dalam istilah politik disebut kedaulatan adalah pada Allah dan manusia hanya sebagai pelaksana kedaulatan Allah dan sebagai khalifah Allah di bumi. Ketiga, sistem politik Islam adalah suatu sistem universal dan tidak mengenal batas-batas dan ikatan-ikatan geografi, bahasa dan kebangsaan.

Berlandaskan tiga dasar keyakinan atau anggapan tersebut, maka lahirlah suatu konsepsi kenegaraan Islam yang pokokpokoknya adalah seperti berikut; Pertama, sistem kenegaraan Islam tidak dapat disebut demokrasi, oleh karena dalam sistem demokrasi kekuasaan negara itu sepenuhnya ditangan rakyat. Sistem politik Islam lebih tepat disebut teokrasi. Kedua, pemerintah atau badan eksekutif hanya dibentuk oleh umat Islam sekaligus hak untuk memecat dari jabatannya. Ketiga, kekuasaan negara dilakukan oleh tiga lembaga atau badan legislatis, eksekutif atau yudikatif. Keempat, Seorang kepala negara harus beragama Islam, laki-laki, shaleh, warga negara yang terbaik, dewasa, sehat fisik dan mental dan kuat komitmennya kepada Islam. Kelima, Keanggotaan majelis syura terdiri dari warga negara yang beragama Islam, dewasa dan laki-laki, shaleh serta cukup terlatih untuk dapat menafsirkan dan menerapkan syariah dan menyusun undang-undang yang tidak bertentangan

${ }^{39}$ Al-Maududi, Tadwin al-Dustur al-Islami, Dar al-Fikr., t.t., hlm. 67 
dengan Al-Quran dan Sunnah Nabi. Keenam, dalam negara Islam terdapat dua kategori kewarganegaraan; warga negara yang beragama Islam dan warga negara bukan Islam. Warga negara yang bukan Islam itu disebut dzimmi (rakyat yang dilindungi). ${ }^{40}$

Berbeda dengan pemikiran Ali abd al-Raziq, ${ }^{41}$ bahwa Nabi Muhammad Saw tidaklah mendirikan suatu daulah (state) melainkan hukumah (pemerintahan; government). Adanya pemerintahan adalah suatu keharusan dan pemerintahan dalam arti hukumah itulah yang dilaksanakan dalam sejarah al-khilafah. Ia menolak al-khilafah sebagai suatu political system atau sistem politik Islam. Ia berpendapat bahwa Nabi tidak mempunyai misi atau mengemban misi Allah untuk mendirikan negara. Masalah-masalah yang mengatur peradilan, jabatan-jabatan pemerintahan, pusat-pusat pemerintahan, semuanya itu diserahkan kepada umat Islam untuk menentukannya berdasarkan akal dan pengalaman-pengalamannya serta kaidah-kaidah politiknya. $^{42}$

Lebih lanjut Abd al-Raziq berpendapat tentang khilafah, bahwa memang benar dalam hidup bermasyarakat tiap kelompok manusia memerlukan penguasa yang mengatur dan melindungi kehidupannya, lepas dari agama dan keyakinan masyarakat, apakah Islam, Nasrani, Yahudi atau atau penganut agama lain, dan bahkan masyarakat yang tidak beragama sekalipun. Penguasa itulah pemerintah. Tetapi pemerintah tersebut tidak harus berbentuk khilafah, melainkan dapat beraneka ragam bentuk dan sifatnya, apakah konstitusional atau kekuasaan mutlak, apakah republik atau diktator. Tegasnya, tiap bangsa harus mempunyai pemerintahan, tetapi baik bentuk maupun sifat pemerintahan itu tidak harus satu, khilafah, dan boleh beraneka ragam.

\section{Faktor-faktor Ikhtilafiyah}

\section{a. Tugas Hakiki Kenabian}

Di antara perdebatan para pemikir Islam adalah tentang tugas hakiki dari para Nabi dan Rasul, ketika para Nabi diutus Allah,

${ }^{40}$ Munawir Sadjali, Op.Cit., 1993, hlm. 165

41 Ali abd al-Raziq

42 Juhaya S.Praja, Sejarah Perkembangan Pemikiran Dalam Islam, (Bandung: Rosdakarya, 1995) hlm. 88 
apakah untuk menyeru Tauhid saja, atau sekaligus harus berkuasa seperti yang terjadi pada Nabi Daud, Nabi Sulaiman, Nabi Yusuf dll., sehingga para Nabi memimpin langsung keberlangsungan suatu negara. Terdapat pula pendapat yang mencoba memisahkan bahwa seorang Nabi menjadi kepala negara merupakan suatu implikasi dari kharisma yang dimiliki bukan merupakan perintah Allah SWT., sehingga tugas para Rasul adalah tetap menyeru (dakwah) kepada Tauhid $^{43}$.

Kebaikan dan kedamaian yang hakiki yang nampak di dalam masyarakat manusia di bawah pimpinan para Nabi. Dan inilah konsepsi paling benar yang diturunkan Allah melalui utusan-Nya kepada manusia. Para Nabi diutus untuk menumpas belenggu perbudakan manusia atas manusia, atau melepaskan tali perhambaan manusia kepada banyak tuhan dan dewa-dewa palsu. Selain itu, untuk meringankan beban manusia dari tindakan kesewenang-wenangan dan kedzaliman, serta untuk mengembalikan eksistensi manusia yang telah jatuh dan lepas dari batas-batas yang telah ditentukan Allah Sang Pencipta. Sekaligus jua mempunyai tugas untuk memberikan sanksi kepada para pendzalim tersebut dengan pelbagai tingkatan adzab. Sedangkan orang-orang yang bernaung di bawah panji kebenaran, diangkat menuju satu kalimat Tauhid, di bawah sistem hidup yang adil. Tidak ada seorang pun yang diperbudak oleh yang lain. Melainkan semuanya adalah hamba-hamba Allah Yang Maha Esa. Dan seluruh Rasul yang diutus kepada makhluk manusia, sejak Nabi Adam as., sampai penutup para Nabi yaitu Nabi Muhammad saw., semuanya Risalah adalah satu. Satu kalimat singkat yaitu Tauhid. ${ }^{44}$

Polemik tersebut terjadi juga pada masa Nabi Muhammad saw., sehingga para pemikir politik Islam terklasifikasi pemikirannya paling tidak kepada tiga pemikiran antara lain; Pertama, Pemikiran fundamentalis, yakni pemikiran yang mengakui kesempurnaan Islam dan manusia hanya tinggal melaksanakan saja termasuk dalam politik. Kedua, Pemikiran sekuler, dimana pemikiran ini memisahkan antara agama dan politik juga antara Nabi/Rasul dengan kepala

43 Moh. Husein Haikal, Hayatuna Muhammad, hlm. 302 dan lihat juga Abdurrohman Asy-Syarqawi, Mubammad Sang Teladan, (Bandung: IBS, 2008)

${ }^{44}$ Lihat Q.11:50, Q.38:65-66 
Negara. Dan ketiga, pemikiran politik Islam yang moderat, yakni pemikiran yang mengakuui kesempurnaan Islam termasuk dalam politik tetapi dalam bentuk nilai-nilai sedangkan pelaksaannya akan ditentukan sesuai dengan ijtihad politik masing-masing. ${ }^{45}$

\section{b. Islam Doktrin (teks Qur'ani) dan Sosiologis (Sunnah Nabi)}

Para pemikir Islam hampir sepakat bahwa dalam teks alQur'an secara harfiyah tidak ada yang menunjukan keharusan/ perintah Allah untuk berdirinya sebuah negara Islam hanya yang menjadi polemik terletak pada tafsirnya, di mana ada ayat yang menunjukkan keharusan menegakkan hukum Allah, bermusyawarah, ${ }^{46}$ menegakkan keadilan, ${ }^{47}$ menjalankan amanah, dll. Hal ini apakah menunjukkan wajibnya mendirikan negara Islam atau nilainilai yang terkanduing dalam Islam tentang kemasyarakatan (muamalah). Dalam hal ini para ulama berbeda pemikiran apakah ayat-ayat ini termasuk mubkamat atau mutasyabihat atau pula qath'i atau donni dan pendekatan bahasa dan ushul fiqih lainnya.

Berikut pula istilah kepemimpinan seperti khalifah, imamah dan ulil amri yang tertera dalam teks Qur'an, secara harfiah tidak menunjukkan sebuah model. Apakah itu menunjukkan sebutan bagi wakil Allah di muka bumi secara personal atau seluruh umat manusia? Atau merupakan sebuah sistem pemerintahan atau kepemimpinan? Hal ini pula yang menjadi multitafsir, karena kalau itu merupakan sebuah sistem pasti akan tertera sebuah mekanisme atau struktur dalam sistem tersebut, tetapi ternyata istilah tersebut tertulis secara umum.

Selain itu, yang menjadi polemik adalah realitas sosiologis yang tidak dapat terbantahkan secara historis di mana Rasululah saw., pernah mendirikan negara madinah dengan berbagai peraturan kenegaraannya. ${ }^{48} \mathrm{Hal}$ ini menjadi perbedaan apakah itu sunnah Nabi yang patut dilaksanakan atau hanya terletak pada nilai-nilai syar'i

\footnotetext{
${ }^{45}$ Munawir Sadjali, Op. Cit

${ }^{46}$ Lihat Q.3:159

${ }^{47}$ Lihat Q.4:58

${ }^{48}$ Lihat Khalil Abdul Karim, Negara Madinah Politik Penaklukan Masyarakat Suku Arab, (Yogyakarta: LKIS, 2005)
} 
yang dilaksanakannya saja.

\section{c. Polemik Sistem Pemerintahan Islam}

Polemik tentang sistem pemerintahan yang beragam mulai dari masa Rasulullah SAW., yang sebahagian para ahli menyatakan lebih demokratis sampai pada masa Khulafa ar-Rasyidin dengan kepemimpinan tidak turun-temurun tetapi di bai'at langsung oleh para shahabat yang lain, bahkan yang disebut zaman ideal, seperti pada turunnya dari Rasulullah kepada Abu Bakar Asy-Syiddiq, Rasulullah tidak pernah menyampaikan kepada siapa kepemimpinan itu harus diteruskan hanya ia pernah menyuruh Abu Bakar untuk menggantikan imam shalat, maka para shahabat mengambil ijtihad mengangkat Abu Bakar. Begitu pula dari Abu Bakar ke Umar, kemudian ke Usman bahkan Umar dengan memberikan 6 calon alternatif dan terakhir kepada Saidina Ali. Tetapi pasca itu turun ke Muawiyah sampai Daulah Ustmaniyah di Turki berubah menjadi sistem monarki/kerajaan. ${ }^{49}$

Permasalahan tersebut menjadi fokus tersendiri di kalangan para pemikir Islam seperti al-Maududi dengan konsep teodemokrasi, mustafa Kemal at-Taturk dengan konsep sekulerisasinya bahkan cenderung ke model demokrasi, ${ }^{50}$ Hasan al-Banna dengan sistem khilafah dan Abd Qadir Audah yang membedakan dari sistem manapun tetapi tidak memiliki bentuknya sendiri.

Begitu pula dalam pemaknaan apakah pemerintahan Islam berbentuk Khilafah (Sunni), dengan bersandar kepada teks al-Qur'an dan memiliki lembaga penasehat (legislatif) majlis syura (Sunni), atau sistem Imamah (Syi'ah) dengan diidentikan dengan shalat dan memiliki lembaga wilayatul faqih. ${ }^{51}$ Terdapat pula yang lebih cenderung bahwa Islam hanya memiliki tata nilai pemeritahan saja. Sedangkan bentuk pemerintahan disesuaikan dengan perkembangan politik.

49 Lihat George Lenczowski, Timur Tengah di Tengah Kancah Dunia, (Bandung: Sinar Baru Algensindo, 2003)

${ }^{50}$ Lihat Mark Juergensmeyer, Menentang Negara Sekuler, Kebangkitan Global Nasionalisme Religius, (Bandung: Mizan, 1998)

51 Lihat Fazlur Rahman dkk., Masalab-Masalah Teori Politik Islam, ( Bandung: Mizan, 1996) 


\section{Penutup}

Prinsip pokok dalam Islam bahwa perbedaan adalah rahmat. Benar dan salah dalam ijtihad sama-sama mendapatkan nilai positif, asal dengan dasar dan tujuan yang baik dan benar. Apalagi dalam ranah politik yang membutuhkan kreatifitas dan inovasi dalam menjalankan sebuah kekuasaan. Ijtihad politik merupakan hal yang mutlak dilakukakan sebab perkembangan politik beriringan erat dengan perkembangan kesadaran rakyat akan hak-hak asasinya. Semakin tinggi kesadaran rakyat melalui jalur pendidikan, maka semakin harus terbuka inovasi politik sehingga aspirasi rakyat dengan penguasa tetap seiring dan sejalan. Dengan demikian akan terwujud politik yang mengarah kepada kebaikan bersama (mashlat al-ammah). Sehingga menuntut pemikiran-pemikiran baru sesuai dengan perkembangan peradaban manusia, sehingga keberadaan ilmu politik Islam dapat menjawab setiap perkembangannya.

\section{DAFTAR PUSTAKA}

Abd Qadir al-Audah, Al-Islam wa Audamu al-Siyasah. Dar al-Kitab alArabi. Kairo, 1957

Abdul Aziz Thaba, M.AA., Drs. Islam Dan Negara Dalam Politik Orde Baru. Gema Insani Press, Jakarta, 1996

Abdul Wahab Khallaf. Al-Siyasah Al-Syar'iyah. Dar al-Ansr. Qairo, 1977

Abu Hasan al-Mawardi. Al-Abkam Ashulthaniyaah wal Wilayatul diniyah. Mustafa al-Asabil Halabi. Mesir cet III t.t

Abu A'la al-Maududi. Al-Dawaun 'ala Harakatil Tadhamuni Islami. T.t - Tadwin Aal-Dusstur al-Islami. Darul Fiqri. T.t

Al-Ghazali, Abu Hamid, Muhammad. Al-Tibru al-Masbuk fi Nasibah al-Muluk. Dar al-Kutub al-Islamiyah. Bairut Libanon

Fazlur Rahman et al. Masalah-masalah Teori Politik Islam. Mizan. Bandung, 1984

Ibn Khaldun. Muqaddimah. Dar al-Fiqr, t.t

Komaruddin Khan. Pemikiran Politik Ibnu Taimiyah

Marcel A. Boisard. Prof.DR. Humanisme Dalam Islam (terjemah). Bulan Bintang. Jakarta, 1980 
Montgomery Watt, Muhammad Prophet and Statesmen, Oxpor University Perss, 1961

Muhammad Husein Fadlullah. Islam dan Logika Kekuasaan (terjemah). Mizan. Bandung, 1995

Munawir Sadzali. Islam dan Tata Negara, ajaran, sejarah dan pemikiran. Jakarta, 1985

Ramli Kabi' AS.MA. Bai'at Satu Prinsip Gerakan Islam. El-Fawaz Press, 1988 
